\title{
Peertechz
}

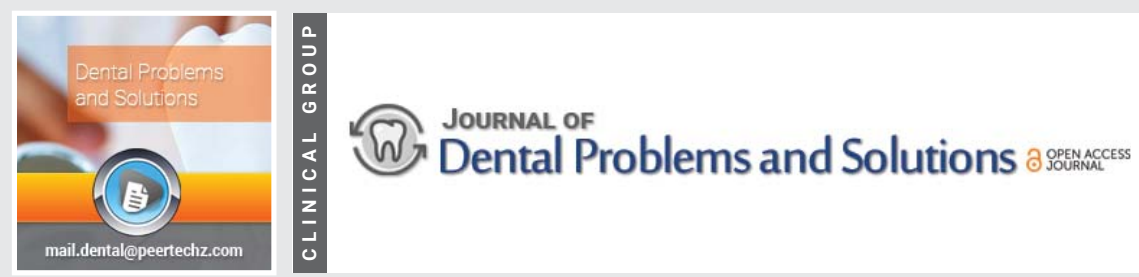

ISSN: $2394-8418$

DOI: https://doi.org/10.17352/jdps

Research Article

\section{Evaluating the knowledge of sports participants regarding dental emergency procedures in National Sports University, Imphal}

\author{
Nandita Gautam ${ }^{1 *}$, Shivalingesh $\mathrm{KK}^{2}$ and Anushtha \\ Kushwaha $^{3}$
}

1,3Department of Public Health Dentistry, Institute of Dental Sciences, Bareilly, India

${ }^{2}$ Professor \& Head, Department of Public Health Dentistry Institute of Dental Sciences, Bareilly, India

Received: 27 July, 2021

Accepted: 11 August, 2021

Published: 12 August, 2021

*Corresponding author: Nandita Gautam, Department of Public Health Dentistry, Institute of Dental Sciences, Bareilly, India, Tel: 9837706470;

E-mail:nanditagautam63552@gmail.com

ORCID: https://orcid.org/0000-0001-9824-6014

Keywords: Sports; Dentistry; Trauma; National sports university

https://www.peertechzpublications.com

\section{Check for updates}

\section{Abstract \\ Objective: To assess awareness of sports players regarding the emergency management of sports injuries in oro facial region. \\ Methods: A self-administered, validated online questionnaire consisting of 10 questions based on knowledge of sports players regarding the emergency management of traumatized teeth was distributed among 90 (30 boxers, 30 mixed martial arts,30 Tae kwon do) players of National Sports University, Imphal. The data obtained were tabulated and statistically analyzed.}

Results: In our study majority of players (86.7\%-96.7\%) encountered trauma while playing and $70 \%-93 \%$ of participants among them has previous experience in managing those trauma cases. Majority of participants reported that soft tissue injuries (70\%-80\%) are more common than hard tissue injuries (20\%-30\%) while playing. Only $13 \%-36 \%$ participants knew that tetanus toxoid injection is necessary in dental trauma cases while $33 \%-60 \%$ of participants has no idea about such measure. On knowledge regarding management of these soft tissue tears $10 \%-33.3 \%$ reported they wipe the area neatly and apply turmeric over it, $30 \%-33 \%$ participants apply an ointment /dettol /spirit and 33.3\%-60\% prefer to visit a dentist. Only 30\%-33.3\% participants of our study reported to seek professional help immediately if a permanent tooth has been knocked out, and $23-26.6 \%$ reported to seek help within 30 minutes.

Conclusion: The level of knowledge, in dental emergency procedures was satisfactory among all participants. Further, rigorous training on Dental Emergency management measures need to be given.

\section{Introduction}

Dental trauma during sports is the major associated factor which links dentistry and sports. This is one of the most recent and evolving dental sectors. Sports dentistry is the treatment of sporting oral / facial injuries and associated oral disorders and manifestations. It has two main components: First to treat orofacial injuries and second to avoid sport-related orofacial injuries [1].

Sports dentistry is the branch of dental sciences include prevention, protection and clinical management of oral and maxillofacial region of athletes and sports active members, it also deals with the safety precautions towards orofacial region and its disorders. Hence precaution, prevention and safety measures are the key factors in avoiding oral and maxillofacial injuries [2]. For all sports, particularly contact, it is normal for children to get injured, with face being the principal area of injury. As dentists, we have different types of dental and facial bone fractures to deal with [3].

The face is the body's most defenseless area, and is often the least protected area. About 11-40 per cent of all sport injuries involve the face. Such injuries most frequently occur by clashing with impacts from a ball or surface or from player to player. A blow to the face may not only inflict damage to the tooth or soft tissue, but can also lead to fractures of the jaw or facial bones, or even head injury. The complex facial anatomy 
poses a challenge for the physicians to diagnose and treat these injuries [4].

Contact sports are described as those sports in which players communicate physically with each other in an effort to prevent the opposing team or person from winning [5]. The National Youth Sports Foundation for the Prevention of Athletic Injuries has identified the most common form of dental / orofacial injuries suffered during sports participation, which include lacerations of the soft tissue, abrasions and contusions, intrusions of the dents or avulsions, fracturing of the crown or / and the root, loss of one or more teeth of maxillary incisors most often [6].

Andersson and Bodin [7] stated that the determining factors for a favorable prognosis of replantation of avulsed tooth are minimal time of the avulsed tooth outside the socket, the storage and transportation medium of the avulsed tooth, and also minimal handling of the root surface and the periodontal ligament. They also stated that prognosis of reimplanted tooth is largely determined in the first 15 min after avulsion. This states that immediate reimplantation is a necessity to achieve a better prognosis on reimplanted tooth [7]. According to the study conducted by Andreasen and Hjorting-Hansen [8], teeth that were reimplanted within $30 \mathrm{~min}$ gave a success rate of $90 \%$, while only $5 \%$ chances of retention to those that were reimplanted after $2 \mathrm{~h}$.

The less common trauma involves zygoma fractures, mandibularfractures, alveolarfractures and temporomandibular joint trauma. Temporomandibular sport injuries and disorders may be caused by direct blows to the temporomandibular region, and indirectly by blows to the chin or laterally to the lower jaw where the force is transferred to one or both jaws. At the same time, the surrounding muscles, articular and extraarticular ligaments, articular disks and capsules, teeth can dissipate and modify the pathogenic effect of force [6].

Orofacial injuries have common consequences and are troublesome. These injuries can affect aspects of life physically, mentally, socially, and economically. Physically, orofacial injuries can lead to abnormal primary teeth exfoliation, permanent teeth eruption failure, unfavorable color changes in the teeth, painful abscesses and dental loss resulting in the injured victim's mouth unesthetic gaps [9]. Protection from sport-related orofacial injuries currently comes in the form of three shielding equipments: mouth guards, facemasks, and helmets [10].

Therefore, this study was conducted to assess the knowledge regarding prevention of traumatic injuries among contact sports players of National Sports University.

\section{Materials and methods}

Our study population consisted of players of National Sports University. The players consent to participate in the study (inclusion criteria) was implied when they clicked on the 'next' button to answer the questionnaire, and they had complete freedom either to decline or answer the questionnaire.
Only the principal investigator had access to the data and no personal details (e-mail address, phone number, name, etc.) were required. Responses were sought from only those players who are involved contact sports like boxing, Tae kwon do and mixed martial arts (MMA) and a submission was considered only when the 'submit' button was clicked at the end of the questionnaire (inclusion criteria). Among total submissions, if a sportsperson failed to answer $\geq 1$ question, it was excluded from the analysis.

The study duration was from $1^{\text {st }}$ August 2020 to $25^{\text {th }}$ august, 2020 , and both convenience sampling (researchers themselves contacted players to participate in the study) and snowball sampling (the participating players were asked to forward the questionnaire to their colleagues) were used so that maximal participation could be ensured. The questionnaire was distributed personally via a quick response $(\mathrm{QR})$ code as well as posted on social media platform like WhatsApp. The questionnaire was divided into 2 sections and had a total of 10 questions. The $1^{\text {st }}$ section contained personal information whereas the $2^{\text {nd }}$ section assessed the knowledge of the participants regarding sports injuries. Data was collected and descriptive statistics were computed for each question's responses. Statistical analysis was done using SPSS version 22. Kruskal Wallis ANOVA was used to compare the responses among the three groups.

\section{Results}

Out of 90 participants 30 each were boxers, mixed martial arts, and taek- wondo players who filled the questionnaire. Differences in their responses were noted among the three groups (Table 1 ).

In our study majority of players $(86.7 \%-96.7 \%)$ encountered trauma while playing and $70 \%-93 \%$ of participants among them has previous experience in managing those trauma cases. Majority of participants reported that soft tissue injuries $(70 \%-80 \%)$ are more common than hard tissue injuries $(20 \%-$ $30 \%$ ) while playing. Only $13.3 \%-40 \%$ participants knew that tetanus toxoid injection is necessary in dental trauma cases while $33 \%-60 \%$ of participants has no idea about such measure. On knowledge regarding management of these soft tissue tears $10 \%-33.3 \%$ reported they wipe the area neatly and apply turmeric over it, 30\%-33\% participants apply an ointment /dettol /spirit and $33.3 \%-60 \%$ prefer to visit a dentist. Only $30 \%-33.3 \%$ participants of our study reported to seek professional help immediately if a permanent tooth has been knocked out, and 23-26.6\% reported to seek help within 30 minutes. Majority $(30 \%-66.7 \%)$ participants of our study do not knew the concept of replant ( put back) the tooth into the socket from which it came in case of trauma, and only $6 \%-16 \%$ of players were aware of this concept and rest participants has no idea. Only $13.3 \%-50.3 \%$ players reported that they will Scrub the tooth gently with a tooth brush to replant a tooth back it the socket if it has fallen into the ground and was covered in dirt, $6 \%-23.3 \%$ reported that they will prefer to rinse the tooth under the tap water and $80 \%$ of taekwondo players reported that they will put the tooth straight back into the socket without doing anything. 
Table 1: Showing responses among three groups.

\begin{tabular}{|c|c|c|c|c|c|}
\hline & Questions & & Boxers & MMA & Tae kwon do \\
\hline 1 & Did you encounter any dental trauma while playing? & $\begin{array}{l}\text { 1) Yes } \\
\text { 2) No }\end{array}$ & $\begin{array}{l}26(86.7 \%) \\
4(13.3 \%)\end{array}$ & $\begin{array}{l}26(86.7 \%) \\
4(13.3 \%)\end{array}$ & $\begin{array}{l}29(96.7 \%) \\
1(3.0 \%)\end{array}$ \\
\hline 2 & Any previous experience in managing trauma cases? & $\begin{array}{l}\text { 1) Yes } \\
\text { 2) No }\end{array}$ & $\begin{array}{l}21(70.0 \%) \\
9(30.0 \%)\end{array}$ & $\begin{array}{l}21(70.0 \%) \\
9(30.0 \%)\end{array}$ & $\begin{array}{l}28(93.3 \%) \\
2(6.7 \%)\end{array}$ \\
\hline 3 & Which type of injury you most often came across? & $\begin{array}{l}\text { 1) Soft tissue injury } \\
\text { 2) Hard tissue injury }\end{array}$ & $\begin{array}{l}21(70.0 \%) \\
9(30.0 \%)\end{array}$ & $\begin{array}{l}21(70.0 \%) \\
9(30.0 \%)\end{array}$ & $\begin{array}{l}24(80.0 \%) \\
6(20.0 \%)\end{array}$ \\
\hline 4 & $\begin{array}{l}\text { Do you think tetanus toxoid injection is necessary in dental trauma } \\
\text { cases? }\end{array}$ & $\begin{array}{l}\text { 1) Yes } \\
\text { 2) No } \\
\text { 3) No idea }\end{array}$ & $\begin{array}{l}11(36.7 \%) \\
9(30.0 \%) \\
10(33.3 \%)\end{array}$ & $\begin{array}{l}12(40.0 \%) \\
8(26.7 \%) \\
10(33.3 \%)\end{array}$ & $\begin{array}{l}4(13.3 \%) \\
8(26.7 \%) \\
18(60.0 \%)\end{array}$ \\
\hline 5 & $\begin{array}{l}\text { Do you have knowledge regarding management of these soft tissue } \\
\text { tears? }\end{array}$ & $\begin{array}{l}\text { 1) Wipe area neatly and apply turmeric } \\
\text { 2) Apply an ointment /Dettol / spirit } \\
\text { 3) Visiting a dentist }\end{array}$ & $\begin{array}{l}10(33.3 \%) \\
10(33.3 \%) \\
10(33.3 \%)\end{array}$ & $\begin{array}{l}10(33.3 \%) \\
17(56.7 \%) \\
3(10.0 \%)\end{array}$ & $\begin{array}{l}3(10.0 \%) \\
9(30.0 \%) \\
18(60.0 \%)\end{array}$ \\
\hline 6 & $\begin{array}{l}\text { If you came across with a knocked out tooth in the hand after an } \\
\text { accident, which would be the first place you would contact and seek } \\
\text { treatment? }\end{array}$ & $\begin{array}{l}\text { 1) General hospital } \\
\text { 2) Visit a dentist }\end{array}$ & $\begin{array}{l}15(50.0 \%) \\
15(50.0 \%)\end{array}$ & $\begin{array}{l}15(50.0 \%) \\
15(50.0 \%)\end{array}$ & $\begin{array}{l}3(10.0 \%) \\
27(90.0 \%)\end{array}$ \\
\hline 7 & $\begin{array}{l}\text { How urgent do you think it is to seek professional help if a permanent } \\
\text { tooth has been knocked out? }\end{array}$ & $\begin{array}{l}\text { 1) Immediately } \\
\text { 2) Within } 30 \text { min } \\
\text { 3) within few hours } \\
\text { 4) Before the next day }\end{array}$ & $\begin{array}{l}10(33.3 \%) \\
8(26.7 \%) \\
6(20.0 \%) \\
6(20.0 \%)\end{array}$ & $\begin{array}{l}10(33.3 \%) \\
8(26.7 \%) \\
6(20.0 \%) \\
6(20.0 \%)\end{array}$ & $\begin{array}{l}9(30.0 \%) \\
7(23.3 \%) \\
8(26.7 \%) \\
6(20.0 \%)\end{array}$ \\
\hline 8 & $\begin{array}{l}\text { Would you replant ( put back) the tooth into the socket from which it } \\
\text { came? }\end{array}$ & $\begin{array}{l}\text { 1) Yes } \\
\text { 2) No } \\
\text { 3) No idea }\end{array}$ & $\begin{array}{l}2(6.7 \%) \\
20(66.7 \%) \\
8(26.7 \%)\end{array}$ & $\begin{array}{l}5(16.7 \%) \\
19(63.3 \%) \\
6(20.0 \%)\end{array}$ & $\begin{array}{l}5(16.7 \%) \\
9(30.0 \%) \\
16(53.3 \%)\end{array}$ \\
\hline 9 & $\begin{array}{l}\text { If you decide to replant a tooth back it the socket, but it has fallen into } \\
\text { the ground and was covered in dirt, what would you do? }\end{array}$ & $\begin{array}{l}\text { 1) Scrub the tooth gently with a tooth brush } \\
\text { 2) Rinse the tooth under the tap water } \\
\text { 3) Put the tooth straight back into the socket } \\
\text { without doing anything } \\
\text { 4) Do not know }\end{array}$ & $\begin{array}{l}16(53.3 \%) \\
7(23.3 \%) \\
0(0 \%) \\
7(23.3 \%)\end{array}$ & $\begin{array}{l}7(23.3 \%) \\
2(6.7 \%) \\
0(0 \%) \\
21(70.0 \%)\end{array}$ & $\begin{array}{l}4(13.3 \%) \\
2(6.7 \%) \\
24(80.0 \%) \\
0(0 \%)\end{array}$ \\
\hline 10 & $\begin{array}{l}\text { If you did not replant the tooth, how would you transport it to the } \\
\text { dentist? }\end{array}$ & $\begin{array}{l}\text { 1) hand } \\
\text { 2) mouth } \\
\text { 3) Water } \\
\text { 4) do not know }\end{array}$ & $\begin{array}{l}16(53.3 \%) \\
0(0 \%) \\
7(23.3 \%) \\
7(23.3 \%)\end{array}$ & $\begin{array}{l}16(53.3 \%) \\
0(0 \%) \\
7(23.3 \%) \\
7(23.3 \%)\end{array}$ & $\begin{array}{l}22(73.3 \%) \\
7(23.3 \%) \\
1(3.3 \%) \\
0(0 \%)\end{array}$ \\
\hline
\end{tabular}

Majority (53.3\%-73.3\%) participants prefer to transport the avulsed tooth in their hand to the dentist, $23.3 \%$ Tae kwon do players reported that they will chose their mouth as transport media, 3.3\%-23.3\% partcipants chosen water for transportation and $23.3 \%$ of boxers and $23.3 \%$ MMA players do not know about such concept of transportation of avulsed tooth.

Through results we arrived at the conclusion that Tae kwon do players has more (facial) injuries as compared to MMA and boxing as the difference between taekwondo and MMA / boxing statistically significant.

\section{Discussion}

Sports can be fun time or a moment of competition. But such fun or competitions can be marred by the unwanted injuries inflicted during sports activities [11].

In our study $96.7 \%$ of Tae kwon do and $86.7 \%$ of MMA and boxers encountered trauma whilst playing amongst which $93.3 \%$ of the taek-wondo players, $70 \%$ of MMA and boxers had previous experience in managing trauma cases. This is found in disparity to the study performed by Zazryn TR, McCrory PR, Cameron PA among Australian professional boxers was found to be $23.3 \%$ [12] and at the same time $23.6 \%$. in study conducted by Ngai KM, Levy F, Hsu EB among American mixed martial arts competitors [13].

In present study the greatest numbers of participant with dental injuries (96.7\%) are of Tae kwon do, which is in a contrast to a study conducted by conducted by Jehad Ajarmah et al $(30 \%)[14]$.

In present study participants most often came across soft tissue injuries (lip, tongue, cheek etc) which was found similar to the results of the study by Chan, et al. [15] In this study, 36.7\% boxers, 40\% MMA athletes and 13.3\% Tae kwon do players agreed that tetanus toxoid injection is necessary in cases of dental trauma. According to research conducted by Fujita Y, Shiono Y, Maki K thorough attempt must be made to determine whether a patient has completed primary immunization. Children with unknown or uncertain previous immunization histories should be considered to have no previous tetanus toxoid doses [16].

With regard to the management of soft tissue tears $60 \%$ Tae kwon do players, 33.3\% boxing, 10\% MMA knew about the importance of emergency visit to nearby dentist and at the same time few chose to clean the wound and apply turmeric over it (33.3\% Boxers, 33.3\% MMA and 10\% Tae kwon do athletes). Majority of players in research carried out by Chada Pujita, Sivakumar Nuvvula, G Shilpa, SVSG Nirmala, V Yamini when it came to the management of the same, participants belonged to rural areas initially preferred managing themselves with traditional household remedies i.e. application of turmeric rather than consulting a dentist, and in the urban areas there was divided opinion in the choice of management of such injuries. None of them preferred to manage such injuries 
using antiseptics, spirit or ointment and it was surprising to know that urban participants preferred the traditional method of managing injuries like application of turmeric in spite of readily available modern medicaments [17].

In our study majority of players believed to take immediate action in case of avulsed tooth which was found similar to the study conducted by Andersson and Bodin who have further stated that the prognosis of reimplanted tooth is largely determined in the first $15 \mathrm{~min}$ after avulsion. This states that immediate reimplantation is a necessity to achieve a better prognosis on reimplanted tooth. ${ }^{7}$ According to the study conducted by Andreasen and Hjorting-Hansen [8], teeth that were reimplanted within $30 \mathrm{~min}$ gave a success rate of $90 \%$, while only $5 \%$ chances of retention to those that were reimplanted after $2 \mathrm{~h}[18]$.

The determining factors for a favorable prognosis of replantation of avulsed tooth are minimal time of the avulsed tooth outside the socket, the storage and transportation medium of the avulsed tooth, and also minimal handling of the root surface and the periodontal ligament. The present study corroborates findings as majority of athletes reported that if tooth has fallen into the ground and was covered in dirt they will scrub the tooth gently with a tooth brush (13.3-53.3\%), it demonstrates that there is need of more information on this subject. In study conducted by Caglar E, Ferreira LP, Kargul B total of $84.3 \%$ of participants said that they would pick up an avulsed tooth from the ground. However, they revealed a lack of awareness regarding the best form of cleaning the tooth, as $67.8 \%$ stated they would clean it with 'water or other liquid,' $10.0 \%$ said they would use 'cloth or paper,' and $22.2 \%$ 'would not clean the tooth [19].

Awareness of possibility of replanting avulsed or knocked out tooth in the survey conducted by Fakhruddin et al., Correa et al. and Perunski et al., was recorded in only $44 \%$ of athletes, and only a small percentage of athletes in this survey (16\%) were familiar with the tooth rescue kit while in our study $6.7 \%$ boxers, $16.7 \%$ MMA athletes and $16.7 \%$ Tae kwon do athletes were aware of replanting avulsed or knocked out tooth which was comparatively low [20]. Different storage media can be used for an avulsed tooth: Milk, saliva, saline solution, and water (in order of preference). Although water is the most readily available, it should be the last option because it causes lysis of vital periodontal cells. ${ }^{21}$ In present study $23.3 \%$ boxing and MMA players and $3.3 \%$ of the Tae kwon do athletes reported that they will carry avulsed tooth in water medium in case of avulsion.

\section{Conclusion}

While contact sports pose a relatively high risk for dental and orofacial trauma, proper treatment can improve outcomes. Prompt referral for complicated crown fractures and temporomandibular joint dislocations is paramount. A toothsaving kit is useful on the sideline. If not available, an avulsed tooth can be transported in milk or saliva. Mouth guards can reduce or eliminate dental injury in most cases.
The level of knowledge in Dental Emergency Procedures was satisfactory among all participants. Further, rigorous training on Dental Emergency management measures need to be given.

\section{References}

1. Sathyaprasad S, Philip PA, Vijaynath S, Neethu SK, Rekha R (2018) Attitude and awareness of using mouthguard among physical instructors in Sullia: A questionnaire study. J Dent Res Rev 5: 124-127. Link: https://bit.ly/3xG2mI0

2. Ali FM, Bhushan P, Saujanya KP, Patil S, Sahane D (2013) Dental trauma: Athletes, coaches, and school teachers must know-A brief review. Saudi Journal of Sports Medicine 13: 7-9. Link: https://bit.ly/2Xad2lJ

3. Andresean JO, Andresean FM (1994) Textbook of Color Atlas of Traumatic Injuries to the Teeth. $3^{\text {rd }}$ ed. Copenhagen: Munksgaard. Link: https://bit.ly/3IXJUbQ

4. Saini R (2011) Sports dentistry. Natl J Maxillofac Surg 2: 129-131. Link: https://bit.ly/3yFUWGn

5. Se Mani S, Aparna S, Madan Kumar PD (2019) Prevalence of orofacial injuries in contact sports: A systematic review. International Journal of Physical Education, Sports and Health6: 39-46. Link: https://bit.ly/2VOhh5H

6. Kumamoto DV, Maeda Y (2004) A literature review of sports-related orofacial trauma. Gen Dent 52: 270-280. Link: https://bit.ly/2Ud9AWw

7. Andersson L, Bodin I (1990) Avulsed human teeth replanted within 15 minutes - a long term clinical follow up study. Endod Dent Traumatol 6: 37-42. Link: https://bit.ly/3iEj7zl

8. Andreasen JO, HjortingHansen E (1996) Replantation of teeth. II. Histological study of 22 replanted anterior teeth in humans. Acta Odontol Scand 24: $287-$ 306. Link: https://bit.ly/3fT3FOw

9. Torg JS (1991) Athletic injuries to the head, neck and face. $2^{\text {nd }}$ ed. St. Louis Mosby.

10. Mellion MB, et al. (2002) Team physician's handbook. $3^{\text {rd }}$ ed. Philadelphia Hanley \& Belfus.

11. Baldava $P$, Anup N (2007) Risk factors for traumatic dental injuries in an adolescent male population in India. J Contemp Dent Pract 8: 35-42. Link: https://bit.ly/3xHTMbX

12. Zazryn TR, McCrory PR, Cameron PA (2009) Injury rates and risk factors in competitive professional boxing. Clin J Sport Med 19: 20-25. Link: https://bit.ly/3IWNIdi

13. Ngai KM, Levy F, Hsu EB (2008) Injury trends in sanctioned mixed martial arts competition: a 5-year review from 2002 to 2007. Br J Sports Med 42: 686-689. Link: https://bit.ly/37yPfox

14. Ajarmah JA, Al Ghanam M, Rassas EA, Alwreikat M, Alwarawreh AM (2019) Comparison of Dental Injuries and Mouthguard uses in three Styles of Martial Arts: Karate, Taekwondo and Jiu-jitsu. Journal of the Royal Medical Services 26: 6-13. Link: https://bit.ly/3shSRxW

15. Pujita C, Nuvvula S, Shilpa G, Nirmala SVSG, Yamini NV (2013) Informative promotional outcome on school teachers'knowledge about emergency management of dental trauma. J Conserv Dent 16: 21-27. Link: https://bit.ly/3IWQwag

16. Chan YM, Williams S, Davidson LE, Drummond BK (2011) Orofacial and denta trauma of young children in Dunedin, New Zealand. Dent Traumatol 27: 199202. Link: https://bit.ly/3CECbW7

17. Fujita $Y$, Shiono $Y$, Maki K (2014) Knowledge of emergency management of avulsed tooth among Japanese dental students. BMC Oral Health 14: 34. Link: https://bit.ly/3s8oXMv 
18. Holan G, Shmueli Y (2003) Knowledge of physicians in hospital emergency rooms in Israel on their role in cases of avulsion of permanent incisors. Int $\mathrm{J}$ Paediatr Dent 13: 13-19. Link: https://bit.ly/2Uexv82

19. Caglar E, Ferreira LP, Kargul B (2005) Dental trauma management knowledge among a group of teachers in two south European cities. Dent Traumatol 21: 258-262. Link: https://bit.ly/3iFTuOu
20. Fakhruddin KS, Lawrence HP, Kenny DJ, Locker D (2007) Use of mouthguards among 12- to 14-year-old Ontario schoolchildren. J Can Dent Assoc 73: 505 Link: https://bit.ly/3shSQtS

21. Flores MT, Andersson L, Andreasen JO, Bakland LK, Malmgren B, et al. (2007) Guidelines for the management of traumatic dental injuries. II. Avulsion of permanent teeth. Dent Traumatol 23: 130-136. Link: https://bit.ly/3CIKss8

\section{Discover a bigger Impact and Visibility of your article publication with}

\section{Peertechz Publications}

\section{Highlights}

* Signatory publisher of ORCID

- Signatory Publisher of DORA (San Francisco Declaration on Research Assessment)

* Articles archived in worlds' renowned service providers such as Portico, CNKI, AGRIS, TDNet, Base (Bielefeld University Library), CrossRef, Scilit, J-Gate etc.

* Journals indexed in ICMJE, SHERPA/ROMEO, Google Scholar etc.

* OAI-PMH (Open Archives Initiative Protocol for Metadata Harvesting)

* Dedicated Editorial Board for every journal

* Accurate and rapid peer-review process

* Increased citations of published articles through promotions

* Reduced timeline for article publication

Submit your articles and experience a new surge in publication services (https://www.peertechz.com/submission).

Peertechz journals wishes everlasting success in your every endeavours.

Copyright: @ 2021 Gautam N, et al. This is an open-access article distributed under the terms of the Creative Commons Attribution License, which permits unrestricted use, distribution, and reproduction in any medium, provided the original author and source are credited.

Citation: Gautam N, Shivalingesh KK, Kushwaha A (2021) Evaluating the knowledge of sports participants regarding dental emergency procedures in National Sports University, Imphal. J Dent Probl Solut 8(2): 052-056. DOI: https://dx.doi.org/10.17352/2394-8418.000105 